\title{
The performance investigation of triangular solar stills having different heat storage materials
}

\author{
Ali Riahi ${ }^{1} \cdot$ Khamaruzaman Wan Yusof $^{1} \cdot$ Balbir Singh Mahinder Singh $^{2} \cdot$ \\ Emmanuel Olisa $^{1} \cdot$ Nasiman Sapari $^{1} \cdot$ Mohamed Hasnain Isa $^{1}$
}

Received: 25 September 2014/ Accepted: 26 June 2015/Published online: 15 July 2015

(c) The Author(s) 2015. This article is published with open access at Springerlink.com

\begin{abstract}
Desalination of water can be achieved via the use of solar stills, especially as they are considered to be the cheapest option for potable water production in remote, arid and small communities with limited availability of freshwater. However, one very common challenge with water production via solar stills is that the amount of water produced is usually low. The aim of this work is to evaluate the productivity enhancement of solar stills using different heat storage materials in the basin. To conduct the experiments, three triangular solar stills were fabricated with similar shapes. In each solar still, a transparent polythene film and a stainless steel trough as cover and basin were used, respectively. Each basin had a length of $50 \mathrm{~cm}$, width of $30 \mathrm{~cm}$ and depth of $8 \mathrm{~cm}$. The solar still configurations differed based on inclusion of $2 \mathrm{~cm}$ depth of black soil or a layer of black paint in the basin. Experimental outputs indicated that there was significant increase in the amount of potable water produced using different heat storage materials under Malaysia tropical condition. Daily cumulative results of water production using these solar stills showed that the solar still with black-painted basin was more efficient; its level of productivity over the conventional solar still and the solar still with black soil in basin was 101 and $20 \%$, respectively. Some water quality parameters were also tested in the laboratory which indicated that the treated water met the WHO standard for drinking water.
\end{abstract}

Ali Riahi

ali_riahiupm@yahoo.com

1 Department of Civil Engineering, Universiti Teknologi PETRONAS, 31750 Tronoh, Perak, Malaysia

2 Department of Fundamental and Applied Sciences, Universiti Teknologi PETRONAS, 31750 Tronoh, Perak, Malaysia
Keywords Solar distillation · Stainless steel basin · Black soil . Black paint $\cdot$ Potable water

\section{Nomenclature}

$T_{\mathrm{w} 1} \quad$ Temperature of water of solar still SS1 $\left({ }^{\circ} \mathrm{C}\right)$

$T_{\mathrm{w} 2} \quad$ Temperature of water of solar still SS2 $\left({ }^{\circ} \mathrm{C}\right)$

$T_{\text {w3 }}$ Temperature of water of solar still SS3 $\left({ }^{\circ} \mathrm{C}\right)$

$T_{\mathrm{a}} \quad$ Temperature of ambient air $\left({ }^{\circ} \mathrm{C}\right)$

$T_{\text {ic1 }} \quad$ Temperature of inner cover of solar still SS1 $\left({ }^{\circ} \mathrm{C}\right)$

$T_{\text {ic2 }}$ Temperature of inner cover of solar still SS2 $\left({ }^{\circ} \mathrm{C}\right)$

$T_{\text {ic3 }}$ Temperature of inner cover of solar still SS3 $\left({ }^{\circ} \mathrm{C}\right)$

$I_{\mathrm{s}} \quad$ Solar irradiance $(\mathrm{W} / \mathrm{m} 2)$

$W_{\mathrm{h} 1} \quad$ Hourly water production of solar still SS1 (L/m2)

$W_{\mathrm{h} 2}$ Hourly water production of solar still SS2 (L/m2)

$W_{\mathrm{h} 3} \quad$ Hourly water production of solar still SS3 (L/m2)

$W_{\mathrm{c} 1}$ Cumulative water production of solar still SS1

(L/m2)

$W_{\mathrm{c} 2}$ Cumulative water production of solar still SS2

(L/m2)

$W_{\mathrm{c} 3}$ Cumulative water production of solar still SS3

$(\mathrm{L} / \mathrm{m} 2)$

$V \quad$ Wind speed $(\mathrm{m} / \mathrm{s})$

\section{Introduction}

To obtain clean and distilled water using solar energy, solar stills are generally categorized into two modes; passive and active solar stills [1]. The distilled water produced using this type of desalination method meets the WHO drinking water standards [2-4], which can be used in remote, coastal, arid and rural areas with limited availability of freshwater, but enough annual sunshine. Previously, some 
researchers have investigated the performance of heat-absorbing materials used in the basin of passive solar stills to enhance distilled water production. The solar still productivity increased by $38 \%$ using black rubber mat as the absorbing material in 1998 [5]. Four passive solar stills were fabricated in Egypt, in the year 2000, where a black rubber with $10 \mathrm{~mm}$ thickness and black gravel (20-30 mm size) were used as heat storage materials in the basin of solar stills and improved the water production by 20 and $19 \%$ at the different conditions of brine volume having $15^{\circ}$ glass cover angle, respectively [6]. A passive triangular solar still (TrSS) using black-painted perspex sheet trough as basin was designed and fabricated in Malaysia, 2014 [3]. The effects of different water depths and operational parameters on its performance were investigated. The results showed that the solar still with lower water depth of $1.5 \mathrm{~cm}$ in the basin had the highest daily water production of $1.55 \mathrm{~kg} / \mathrm{m}^{2}$ days [3]. A comparative investigation was conducted by constructing four different types of passive double slope solar stills with similar shapes in Malaysia, 2014 [7]. The cover and frame of each solar still were fabricated using the same materials as TrSS [3], except the basin, which was made of stainless steel trough to prevent the basin metal that is exposed to water and humid air inside the solar still from corroding [8]. The results showed an increase in the cumulative water productivity up to $2.36 \mathrm{~L} / \mathrm{m}^{2}$ using black paint layer in basin as compared to the productivity of $1.6,1.24$ and $1.05 \mathrm{~L} / \mathrm{m}^{2}$, using $50 \mathrm{~W}$ PV-DC heater integrated with solar still, sea sand layer in the basin and only applied stainless steel basin, respectively [7]. Water production rate increased by $15.3 \%$ when sponge was used as the heat-absorbing material in a single basin solar still in India [9], while water production rate increased by $45.5 \%$ when fins were used in the same solar still basin. A fin-type solar still was fabricated in India [10] and various experiments were conducted using different heat storage materials, such as sponges, pebbles, black rubber and sand in the solar still basin to compare the yield enhancement. The highest productivity ratio was 75 and $74 \%$ during high and low solar intensities by the use of sand sponge in the fin-type solar still basin as compared to the other types of solar stills. The effects of using yellow sponge cubes, black steel, black coal and black sponge cubes as heat storage materials in basin of single slope solar still were studied comparatively in Jordan [11]. The results showed an enhancement in production ratio using yellow sponge cubes as compared to the other absorbing materials. A comparative study was conducted in Mehsana [12] using suspended aluminum and galvanized iron floating plates as energy-absorbing plates in the basin of conventional solar still. A significant increase in cumulative water production was achieved using suspended aluminum floating plates in the basin of solar still as compared to the solar still using galvanized iron floating plates and conventional solar still, respectively. The aim of this comparative work is to investigate the performance of three polythene film cover TrSS using different heat storage materials in the basin (e.g., only stainless steel basin, $2 \mathrm{~cm}$ depth of black soil added in the stainless steel basin or a layer of flat black paint in the stainless steel basin, respectively). The novelty of this research is basically related to the different absorbing approaches used in the solar still. In one of the stainless steel basins that was not painted, black soil was used as the absorbing material and compared against stainless steel basin that was painted with flat black paint and another basin that was not painted. The performance of the black-painted basin has been investigated earlier and reported in [7].

\section{Methodology}

Figure 1a, b shows the schematic representation and photograph of the experimental setup of three units of solar stills, respectively. Three types of single basin double slope solar stills were constructed with similar triangular shapes. Each of them had a stainless steel trough as basin with length of $50 \mathrm{~cm}$, width of $30 \mathrm{~cm}$ and depth of $8 \mathrm{~cm}$ (volume $12 \mathrm{~L}$ ). The double slope frame, cover and trough (basin) of all solar stills were made of PVC pipe, transparent polythene film and stainless steel, respectively [7]. The stainless steel basin was employed to prevent the basin metal that is exposed to water and humid air inside the still from corroding [8]. The solar stills were light and, hence, portable. The solar stills were made using local and cheap materials [3].

The total fabrication cost of conventional solar still having a black-painted layer in basin was around RM 82.5 or US\$25.8 (Table 1). The covers of solar stills are usually made of heavy glass and this can make fabrication difficult, particularly in remote, arid and coastal areas. PVC pipes and polythene films have durability of 3-5 years [13] which is longer as compared to 2 years for vinyl chloride sheets [14]; thus, polythene film was selected as cover material for solar stills in this work. The three types of solar stills studied are:

Solar still 1 (SS1)—conventional solar still

Solar still 2 (SS2)—conventional solar still with black soil in the basin

Solar still 3 (SS3) — conventional solar still with blackpainted basin.

A $2 \mathrm{~cm}$ black soil was included in the solar still basin as indicated above. Experiments were conducted for a period of 3 days in Universiti Teknologi PETRONAS (UTP) 


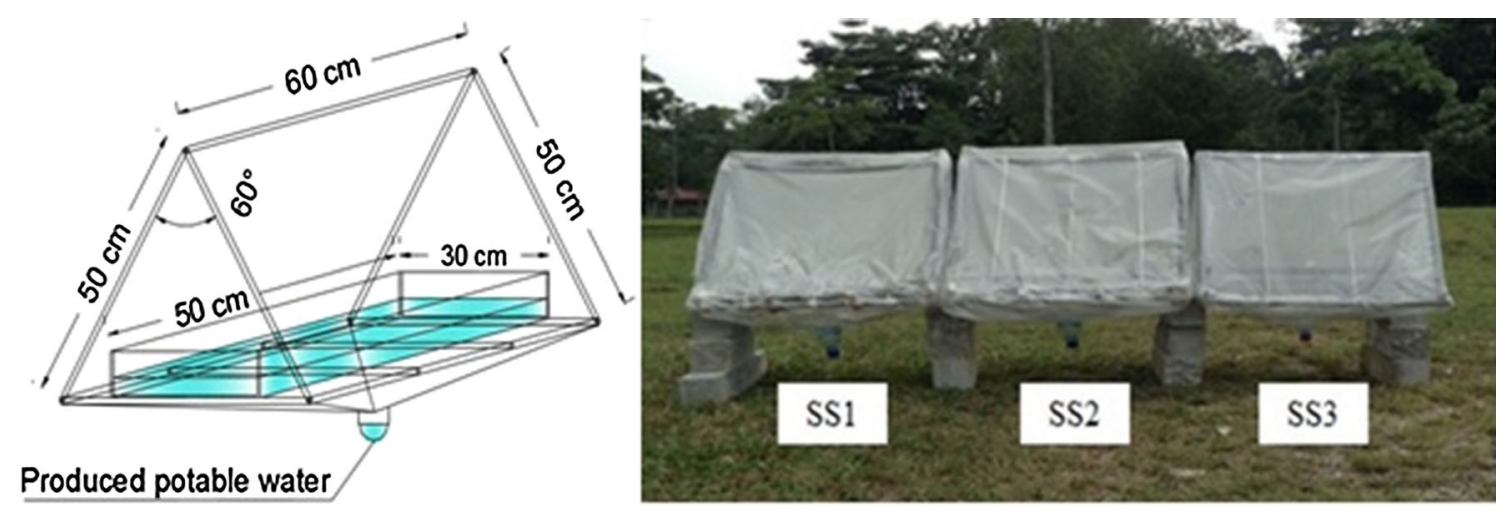

Fig. 1 a Schematic diagram of the solar still and $\mathbf{b}$ photograph of the experimental setup

Table 1 Fabrication cost of double slope black-painted basin solar still

\begin{tabular}{|c|c|c|c|}
\hline Items & Quantity & Unit cost (RM) & Cost (RM) \\
\hline Polythene film cover (0.15 mm thickness) & $1.2 \mathrm{~m}^{2}$ & $\mathrm{RM} 1.80 / \mathrm{m}^{2}$ & 2.20 \\
\hline PVC pipe frame (15 mm diameter) & $4.8 \mathrm{~m}$ & $\mathrm{RM} 6.00 / \mathrm{m}$ & 28.20 \\
\hline Stainless steel tray & 1 & 40.00 & 40.00 \\
\hline Plastic rope & $30 \mathrm{~m}$ & RM 12.00/roll & 3.60 \\
\hline Transparent tape & 1 & 2.50 & 2.50 \\
\hline Flat black spray & 1 & 6 & 6 \\
\hline Total cost & & & 82.50 \\
\hline
\end{tabular}

$\mathrm{US} \$ 1 \approx \mathrm{RM} 3.20$

Table 2 Experimental instrument with accuracy, range and percentage errors

\begin{tabular}{llll}
\hline Instruments & Accuracy & Range & $\%$ Error \\
\hline Digital multimeter & $\pm 1{ }^{\circ} \mathrm{C}$ & $0-100{ }^{\circ} \mathrm{C}$ & 1 \\
Pyranometer & $\pm 1 \mathrm{~W} / \mathrm{m}^{2}$ & $0-3000 \mathrm{~W} / \mathrm{m}^{2}$ & 0.5 \\
Measuring cylinder & $\pm 0.5 \mathrm{ml}$ & $0-50 \mathrm{ml}$ & 0.5 \\
Anemometer & $\pm 0.1 \mathrm{~m} / \mathrm{s}$ & $0.2-30 \mathrm{~m} / \mathrm{s}$ & 1 \\
\hline
\end{tabular}

campus to analyze the performance of the three different absorption materials in the basin of solar stills:

Solar stills 1, 2 and 3 were exposed to similar solar irradiance in an open field (Fig. 1b).

The temperature of water in the different basins, inner cover and outer cover temperature of solar stills and ambient temperature were measured at time intervals of 30 min using digital multimeter. Solar irradiance in UTP campus was measured and collected every 5 min using a pyranometer. Wind speed was also measured and collected every 5 min using an anemometer.

Each solar still basin was filled with $4.5 \mathrm{~L}$ of lake water ( $3 \mathrm{~cm}$ deep) for the experiments. Water vapor was condensed on the transparent cover and naturally collected as shown in Fig. 1. Table 2 shows the different experimental instruments as well as their accuracies used to measure temperature, solar irradiance and wind speed.

\section{Results and discussion}

Table 3 shows the variations of average solar irradiance, average wind speed, average temperature of water $\left(T_{\mathrm{w}}\right)$, average inner cover temperature for three solar stills $\left(T_{\mathrm{ic}}\right)$, average ambient temperatures $\left(T_{\mathrm{a}}\right)$ and cumulative water productivities $\left(W_{\mathrm{C}}\right)$ from 8 am to $6 \mathrm{pm}$ for three solar stills for 3 days, 11th, 14th and 19th of July 2014. It was observed that with the increase of average solar irradiance and decrease in average wind speed, average water temperature and cumulative productivities increased, respectively, for all three solar stills (Table 3). The highest average solar irradiance occurred on 19.07.2014 with the value of $562 \mathrm{~W} / \mathrm{m}^{2}$ which caused the average water temperature and cumulative productivity reached to attain the following values: $42.18,43.18$ and $43.63{ }^{\circ} \mathrm{C}$ and 1.106 , 1.860 and $2.227 \mathrm{~L} / \mathrm{m}^{2}$ for $\mathrm{SS} 1, \mathrm{SS} 2$ and $\mathrm{SS} 3$, respectively, for a period of three experimental days. The results in Table 3 also showed that these values were always higher than the corresponding values on the 11th and 14th July 2014 due to the higher average of solar irradiance $\left(I_{\mathrm{s}}\right)$. It was also observed that the solar still using black-painted basin (SS3) had higher values of average temperature of water and inner cover and cumulative productivities as compared to the corresponding values for SS1 and SS2 during these days (Table 3). 
Table 3 The average of $I_{\mathrm{s}}, V, T_{\mathrm{w}}, T_{\mathrm{ic}}, T_{\mathrm{a}}$ and $W_{\mathrm{C}}$ from 8 am to $6 \mathrm{pm}$ for three solar stills for a period of 3 days

\begin{tabular}{|c|c|c|c|c|c|c|c|}
\hline Date & Average $I_{\mathrm{s}}\left(\mathrm{W} / \mathrm{m}^{2}\right)$ & Average $V(\mathrm{~m} / \mathrm{s})$ & Solar still & Average $T_{\mathrm{W}}\left({ }^{\circ} \mathrm{C}\right)$ & Average $T_{\text {ic }}\left({ }^{\circ} \mathrm{C}\right)$ & Average $T_{\mathrm{a}}\left({ }^{\circ} \mathrm{C}\right)$ & $W_{\mathrm{C}}\left(\mathrm{ml} / \mathrm{m}^{2}\right)$ \\
\hline \multirow[t]{3}{*}{11.07 .2014} & \multirow[t]{3}{*}{507.66} & \multirow[t]{3}{*}{0.956} & SS1 & 40.19 & 33.66 & \multirow[t]{3}{*}{30.00} & 1090 \\
\hline & & & $\mathrm{SS} 2$ & 40.29 & 33.33 & & 1620 \\
\hline & & & SS3 & 40.62 & 33.52 & & 2157 \\
\hline \multirow[t]{3}{*}{14.07 .2014} & \multirow[t]{3}{*}{446.08} & \multirow[t]{3}{*}{2.122} & SS1 & 39.62 & 33.76 & \multirow[t]{3}{*}{29.80} & 1073 \\
\hline & & & $\mathrm{SS} 2$ & 39.71 & 33.10 & & 1337 \\
\hline & & & SS3 & 40.00 & 33.48 & & 1846 \\
\hline \multirow[t]{3}{*}{ 19.07.2014 } & \multirow[t]{3}{*}{562.00} & \multirow[t]{3}{*}{1.34} & SS1 & 42.18 & 36.18 & \multirow[t]{3}{*}{32.00} & 1106 \\
\hline & & & $\mathrm{SS} 2$ & 43.18 & 35.9 & & 1860 \\
\hline & & & SS3 & 43.63 & 36.18 & & 2227 \\
\hline
\end{tabular}

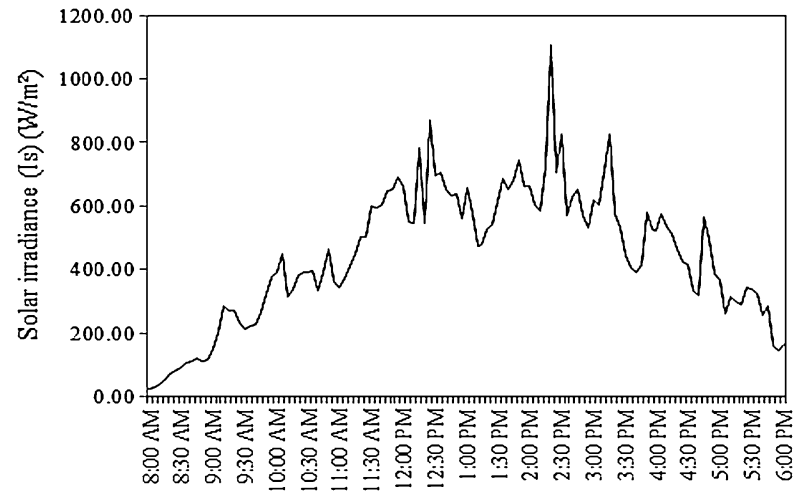

Fig. 2 Diurnal variations of solar irradiance $\left(I_{\mathrm{S}}\right)$ from 8 am to $6 \mathrm{pm}$ on a typical day on 14th July 2014

The cumulative experimental productivity for SS3 reached the highest value of $2.227 \mathrm{~L} / \mathrm{m}^{2}$ with the average $T_{\mathrm{W}}$ of $43.63{ }^{\circ} \mathrm{C}$ and average $I_{\mathrm{s}}$ of $562 \mathrm{~W} / \mathrm{m}^{2}$ on 19.07 .2014 , due to the use of black paint in basin as well as availability of solar irradiance, while the highest obtained cumulative productivities for SS1 and SS2 were 1.106 and $1.86 \mathrm{~L} / \mathrm{m}^{2}$ with the average water temperatures of 42.18 and $43.18{ }^{\circ} \mathrm{C}$ and average inner cover temperatures of 36.18 and $35.9^{\circ} \mathrm{C}$ on 19.07.2014 with the use of conventional solar still and conventional solar still having black soil in the basin. It is concluded that the highest cumulative productivity for SS3 is almost two times higher than the highest water produced by SS1 (Table 3).

\section{Effect of solar irradiance and wind speed on the temperatures of water, temperature of inner and outer cover of three solar stills and ambient air temperature}

Figures 2 and 3 show the variations of solar irradiance $\left(I_{\mathrm{S}}\right)$ and wind velocity $(V)$, respectively, from 8 am to $6 \mathrm{pm}$ in a typical day on the 14th of July 2014. Figures 4, 5 and 6 show the diurnal variations of temperature of water, temperature of inner cover of SS1, SS2 and SS3, respectively,

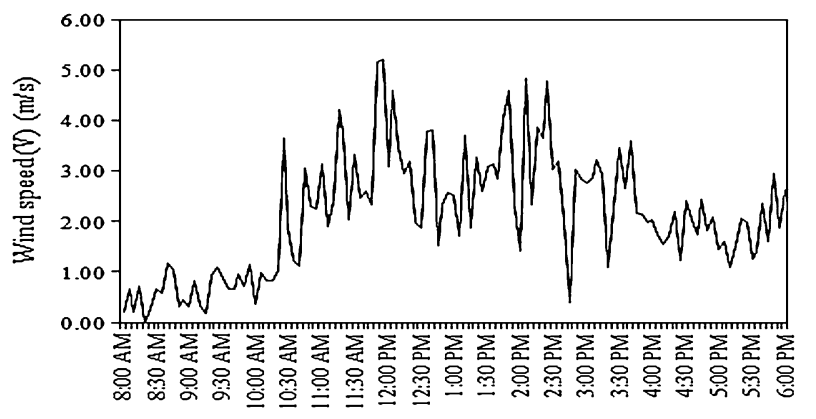

Fig. 3 Diurnal variations of wind speed (V) from 8 am to $6 \mathrm{pm}$ on a typical day on 14th July 2014

versus hourly water production of the three solar stills at time intervals of $30 \mathrm{~min}$ in a typical day on the 14th of July 2014. The temperature increase and decrease corresponded to the increase and decrease in solar irradiance throughout the day (Figs. 2, 4, 5, 6).

It is observed that when solar irradiance reached a maximum value from $22.05 \mathrm{~W} / \mathrm{m}^{2}$ at $8: 00 \mathrm{am}$ to $1107.45 \mathrm{~W} / \mathrm{m}^{2}$ at $2: 30 \mathrm{pm}$, the highest $T_{\mathrm{W} 1}, T_{\mathrm{W} 2}, T_{\mathrm{W} 3}$ and $T_{\mathrm{a}}$ were recorded at 2:30 pm with the values of $47,47,48$ and $34{ }^{\circ} \mathrm{C}$, respectively, while the corresponding maximum inner cover temperatures $T_{\mathrm{ic} 1}, T_{\mathrm{ic} 2}$ and $T_{\mathrm{ic} 3}$ were 39,38 and $38{ }^{\circ} \mathrm{C}$. It was also observed that the solar irradiance had a correlating relationship with the wind speed as can be readily seen from the graphs: when there was an increase in solar radiation intensity, there was a corresponding decline in wind speed (Figs. 2, 3).

\section{Effects of solar irradiance, wind speed and water temperature on hourly water production}

Figures 4, 5 and 6 show the hourly water production for three solar stills corresponding to solar irradiance and water temperatures. The maximum $I_{\mathrm{s}}$ occurred at $2: 30 \mathrm{pm}$ and the highest $\mathrm{Tw}$ for three solar stills occurred from 2:30 pm until 3:00 pm (Figs. 2, 4, 5, 6). It is observed that 

temperatures of water and inner cover of SS1, ambient air temperature and hourly water production of SS1, respectively, from 8 am to $6 \mathrm{pm}$ on a typical day on 14th July 2014
Fig. 4 Diurnal variations of

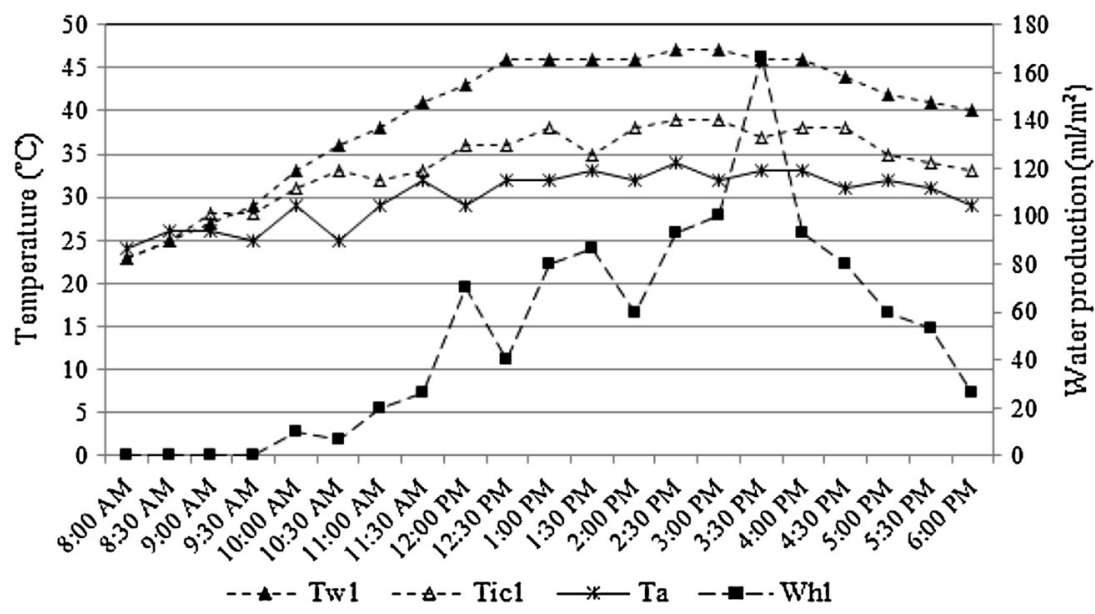

Fig. 5 Diurnal variations of temperatures of water and inner cover of SS2 and hourly water production of SS2, respectively, from 8 am to $6 \mathrm{pm}$ on a typical day on 14th July 2014

Fig. 6 Diurnal variations of temperatures of water and inner cover of SS3 and hourly water production of SS3, respectively, from 8 am to $6 \mathrm{pm}$ on a typical day on 14th July 2014
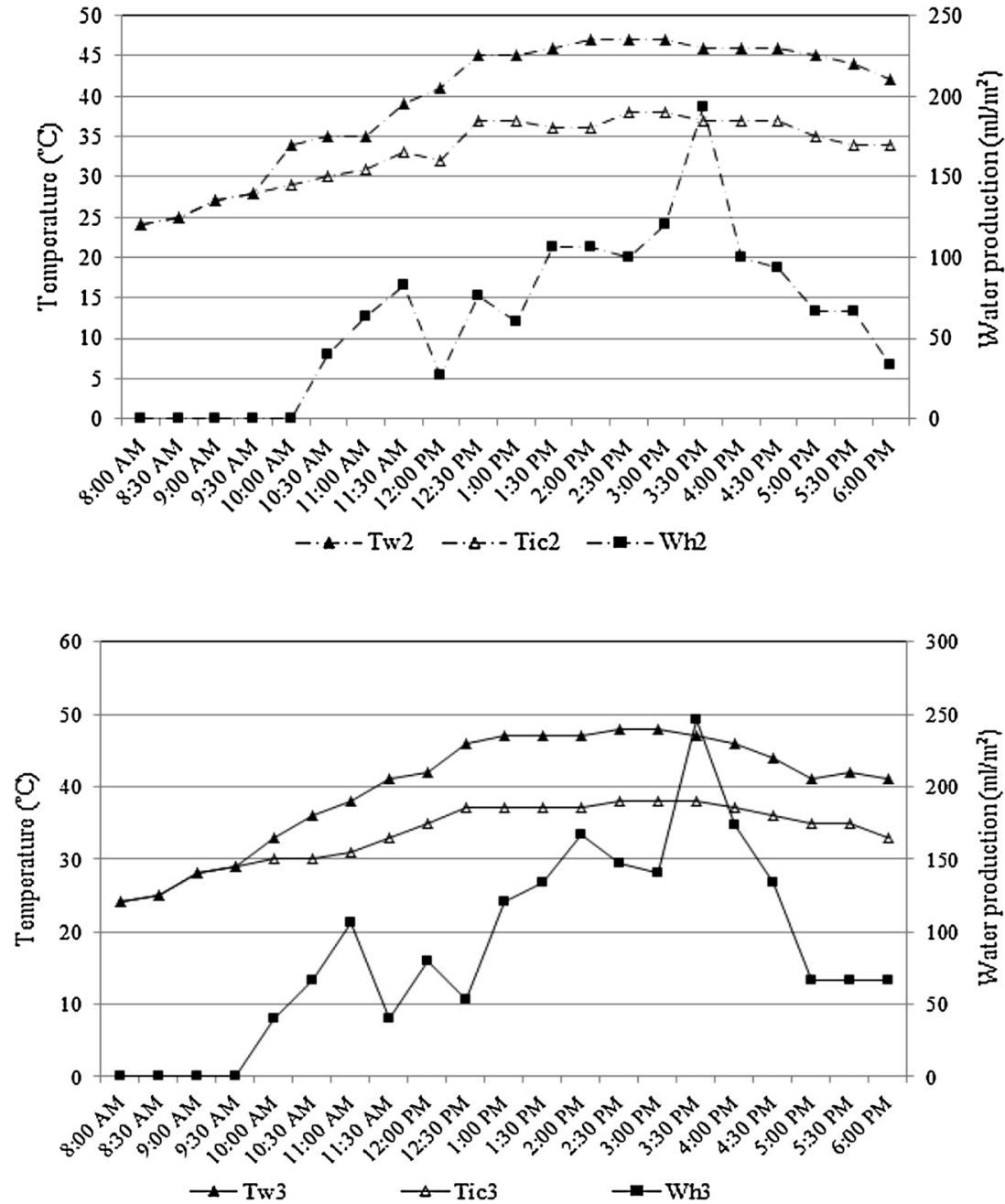

as the solar irradiance increased, there was also a corresponding increase in the water temperature, which resulted in the highest evaporation experienced during the experiment. At this time also, there was a concurrent decline in the speed of wind (Figs. 2, 3, 4, 5, 6). At 2:30 pm, solar irradiance reached its peak value of $1107.45 \mathrm{~W} / \mathrm{m}^{2}$, which resulted in the water temperature having its highest values of 47,47 and $48{ }^{\circ} \mathrm{C}$ for SS1, SS2 and SS3, respectively. The hourly water production rate was observed to have climaxed at 3:30 pm, when the wind speed was seen to 
have increased significantly during the period of the experiment, while solar irradiance and water temperature had reduced and resulted in the highest condensation to be experienced (Figs. 2, 3, 4, 5, 6). Such trend has also been reported in previous works [15, 16]. The highest hourly water production for solar stills SS1 (Wh1), SS2 (Wh2) and SS3 (Wh3) were 166.67, 193.33 and $247 \mathrm{~mL} / \mathrm{m}^{2}$, respectively, obtained at $3: 30 \mathrm{pm}$. With the decrease of solar irradiance from $1107.45 \mathrm{~W} / \mathrm{m}^{2}$ at $2: 30 \mathrm{pm}$ to $443.25 \mathrm{~W} / \mathrm{m}^{2}$ at $3: 30 \mathrm{pm}$, the water temperature of three solar stills also decreased to the values of 46,46 and $47{ }^{\circ} \mathrm{C}$ for SS1, SS2 and SS3, respectively, which caused the highest condensation rate or water production rate of the three stills to occur at this time.

\section{Cumulative water production}

Figure 7 and Table 3 show the variations in cumulative water production for three solar stills in a typical day on 14th July 2014. Water produced from SS1 $\left(W_{\mathrm{C} 1}\right)$ was the least throughout the day. At the end of the experiment, the total amount of water produced from SS1, SS2 and SS3 were $1.073,1.337$ and $1.846 \mathrm{~L} / \mathrm{m}^{2}$, respectively. $W_{\mathrm{C} 3}$ was the highest amount of water produced from all solar stills, confirming that the configuration adopted in SS3 was the most effective. It can be concluded that the modifications made on the conventional solar still, i.e., use of black soil or use of black paint in the basin was instrumental in the production of more water from the solar stills. The application of black paint in the solar still basin produced the highest quantity of water as compared to the other configurations investigated, due to the effect of black paint in the basin which resulted in higher heat absorption for water evaporation [7].

In this study, SS3 yielded a maximum cumulative water production of $2.227 \mathrm{~L} / \mathrm{m}^{2}$ using black paint in the stainless steel basin, while a modified solar distillation system in India [10] produced $1.8 \mathrm{~L} / \mathrm{m}^{2}$ using stepped solar still with fin, pebble and sponge together with solar pond. This research also shows higher water productivity compared to passive solar still studies in Turkey [17], Malaysia [3, 18, 19] and Jordan [20].

\section{Water quality analysis}

Table 4 shows the water quality parameters of the water produced from lake water, with the WHO standards for drinking water. The values of $\mathrm{pH}$, total dissolved solids (TDS), nitrate, nitrite, sulfate, iron, turbidity and color reduced from 7.25, 380, 1, 0.96, 2.37, $18.67 \mathrm{mg} / 1,9.8 \mathrm{NTU}$ and 8 Hazen unit before experiment to $6.63,250,0.4$, $0.041,0.5,0.08 \mathrm{mg} / 1,1.40 \mathrm{NTU}$ and 0 Hazen unit after the experiment, respectively, which showed that the treated distilled water was within the accepted range of WHO drinking water standards in this work [21, 22].

\section{Conclusion}

Despite daily fluctuations due to cloud coverage, solar energy can be effectively harnessed and converted to thermal energy for potable water production using solar still with black paint in the stainless steel basin. The conventional solar still using direct sun radiation only produced $1.09,1.073$ and $1.106 \mathrm{~L} / \mathrm{m}^{2}$ of potable water, while the solar distillation system with added black soil in the basin produced $1.62,1.337$ and $1.86 \mathrm{~L} / \mathrm{m}^{2}$ on 11,14 and 19 July 2014 , respectively, under Malaysia's meteorological conditions. Water production can be enhanced to $2.157,1.846$ and $2.227 \mathrm{~L} / \mathrm{m}^{2}$, respectively, by adding black-painted basin to the conventional type of solar still. A comparative research of maximum cumulative water production among these
Fig. 7 Variations of cumulative water productivity for three solar stills from 8 am to $6 \mathrm{pm}$ on a typical day on 14th July 2014

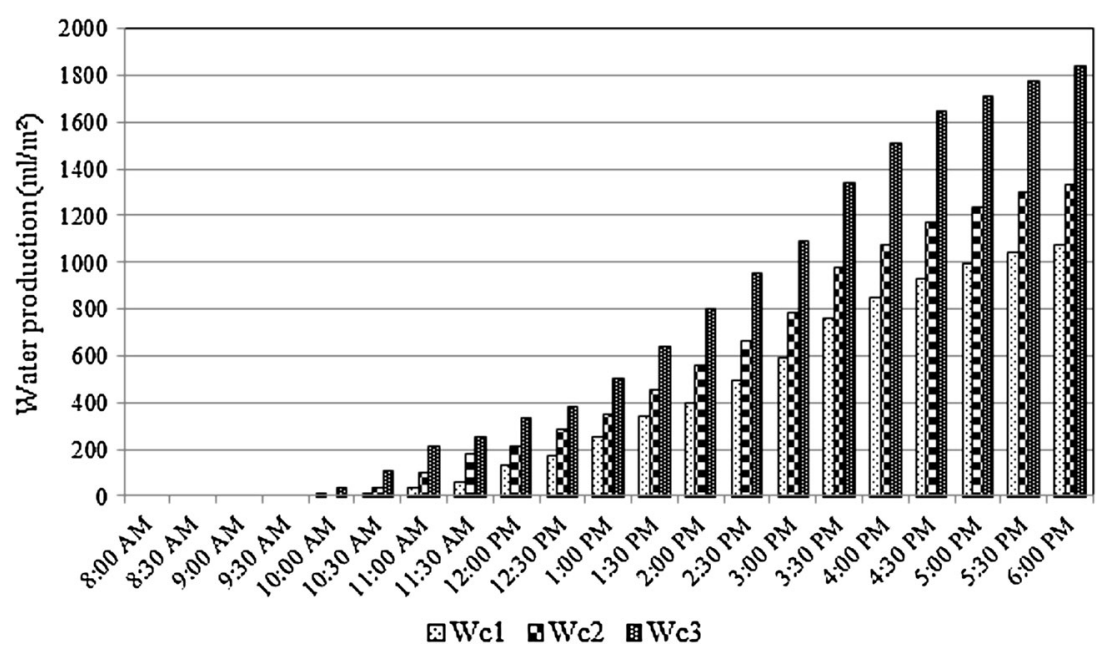


Table 4 Performance assessment of solar stills used for treatment of the lake water in the UTP campus

\begin{tabular}{llll}
\hline Water quality parameter & Lake water (average) & Distilled water (average) & WHO standards [21, 22] \\
\hline $\mathrm{pH}$ & 7.25 & 6.63 & $6.5-8.0$ \\
Total dissolved solids (mg/l) & 380 & 250 & 600 \\
Nitrate (mg/l) & 1 & 0.4 & 50 \\
Nitrite (mg/l) & 0.096 & 0.041 & 0.05 \\
Sulfate (mg/l) & 2.37 & 0.5 & 250 \\
Iron (mg/l) & 18.67 & 0.08 & 0.3 \\
Turbidity (NTU) & 9.8 & 1.40 & 5 \\
Color (Hazen unit) & 8 & 0 & 5 \\
\hline
\end{tabular}

solar stills showed that solar still with black-painted basin was more efficient. It produces around 101 and $20 \%$ more potable water than a conventional solar still and solar still with black soil in the basin from 8 am to 6 pm, respectively. The solar still with black-painted basin in this study produced more water than the conventional still and solar still with black soil in the basin as well. The water quality parameters of the water produced were also tested and showed to be within the acceptable range of World Health Organization (WHO) drinking water standard. Therefore, it is concluded that the solar stills used in this work are able to provide potable water from lake water for drinking purpose.

Acknowledgment The authors highly appreciate Universiti Teknologi PETRONAS (UTP) for providing the fund (Grant Code: STIRF NO. 0153AA-C55) and necessary environment to carry out this research.

Open Access This article is distributed under the terms of the Creative Commons Attribution 4.0 International License (http://creative commons.org/licenses/by/4.0/), which permits unrestricted use, distribution, and reproduction in any medium, provided you give appropriate credit to the original author(s) and the source, provide a link to the Creative Commons license, and indicate if changes were made.

\section{References}

1. Malik, M.A.S., Tiwari, G.N., Kumar, A., Sodha, M.S.: Solar Distillation. Pergaman Press, Oxford (1982)

2. Jasrotia, S., Kansal, A., Kishore, V.V.N.: Application of solar energy for water supply and sanitation in arsenic affected rural areas: a study for Kaudikasa village, India. J. Clean. Prod. 37, 389-393 (2012)

3. Ahsan, A., Imteaz, M., Thomas, U.A., Azmi, M., Rahman, A., Nik Daud, N.N.: Parameters affecting the performance of a low cost solar still. Appl. Energy 114, 924-930 (2014)

4. Syuhada, N., Ahsan, A., Thomas, U.A., Imteaz, M., Ghazali, A.H.: A low cost solar still for pure water production. J. Food Agric. Environ. 11, 990-994 (2013)

5. Akash, B.A., Mohsen, M.S., Osta, O., Elayan, Y.: Experimental evaluation of a single-basin solar still using different absorbing materials. Renew. Energy 14, 307-310 (1998)

6. Nafey, A.S., Abdelkader, M., Abdelmotalip, A., Mabrouk, A.A.: Solar still productivity enhancement. Energy Convers. Manag. 42, 1401-1408 (2001)
7. Riahi, A., Yusof, K.W., Isa, M.H., Singh, B.S.M., Malakahmad, A., Sapari, N.B.: Experimental investigation on the performance of four types of solar stills in Malaysia. Appl. Mech. Mater. 567, 56-61 (2014)

8. Eng, N.H., Lim, E.W., Lim, Y.C.: Focus Goal SPM Chemistry. Pelangi, Malaysia (2010)

9. Velmurugan, V., Gopalakrishnan, M., Raghu, R., Srithar, K.: Single basin solar still with fin for enhancing productivity. Energy Convers. Manag. 49, 2602-2608 (2008)

10. Velmurugan, V., Deenadayalan, C.K., Vinod, H., Srithar, K.: Desalination of effluent using fin type solar still. Energy 33, 1719-1727 (2008)

11. Abu-Hijleh, B., Rababa'h, H.M.: Experimental study of a solar still with sponge cubes in basin. Energy Convers. Manag. 44, 1411-1418 (2003)

12. Panchal, H., Shah, P.K.: Investigation on solar stills having floating plates. Int. J. Energy Environ. Eng. 3, 1-5 (2012)

13. Ahsan, A., Rahman, A., Shanableh, A., Nik Daud, N.N., Mohammed, T.A., Mabrouk, A.N.A.: Life cycle cost analysis of a sustainable solar water distillation technique. Desalin Water Treat. 51, 1-8 (2013)

14. Ahsan, A., Imteaz, M., Rahman, A., Yusuf, B., Fukuhara, T.: Design, fabrication and performance analysis of an improved solar still. Desalination 292, 105-112 (2012)

15. El-Sebaii, A.A.: Effect of wind speed on active and passive solar stills. Energy Convers. Manag. 45, 1187-1204 (2004)

16. Zurigat, Y.H., Abu-Arabi, M.K.: Modelling and performance analysis of a regenerative solar desalination unit. Appl. Therm. Eng. 24, 1061-1072 (2004)

17. Aybar, H.S., Assefi, H.: Simulation of a solar still to investigate water depth and glass angle. Desalin. Water Treat. 7, 35-40 (2009)

18. Riahi, A., Yusof, K.W., Sapari, N.B., Malakahmad, A., Hashim, A.M., Singh, B.S.M.: Potable water production by using triangular solar distillation systems in Malaysia. Proc. IEEE Conf. Clean Energy Technol. 6775679, 473-477 (2013). doi:10.1109/ CEAT.2013.6775679

19. Riahi, A., Yusof, K.W., Sapari, N.B., Singh, B.S.M., Hashim, A.M.: Novel configurations of solar distillation system for potable water production. IOP Conf. Ser. Earth Environ. Sci. 16, 012135 (2013). doi:10.1088/1755-1315/16/1/012135

20. Tarawneh, M.S.K.: Effect of water depth on the performance evaluation of solar still. Jordan J. Mech. Ind. Eng. 1, 23-29 (2007)

21. World Health Organization. Guidelines for drinking-water quality (electronic resource): Incorporating the first and second Addenda, Recommendations-3rd edn, vol. 1, Geneva, Switzerland (2008). http://www.who.int/water_sanitation_health/dwq/ fulltext.pdf Accessed 15 May 2011

22. World Health Organization. Guidelines for Drinking-Water Quality, 4th edn, Geneva, Switzerland (2011). http://whqlibdoc. who.int/publications/2011/9789241548151_eng.pdf?ua=1 on Accessed 10 March 2015 